\title{
The engagement of the Social-Cultural Capital in the development of Sustainable Urban Structure under Risk Conditions.
}

\author{
Prof. Carolina Arriagada-Sickinger ${ }^{1}$, Dr. Irina Tumini ${ }^{2}$, Prof. Angela Poletti ${ }^{3}$, \\ Dr. Sergio Baeriswyl ${ }^{4}$
}

\begin{abstract}
The importance of the human capital in the sustainable development of the urban network has relieved the cultural and social development as fundamental features of local Community. Empirical studies have demonstrated that the social capital, under risk conditions, evolves toward new form of organization to face the emergency. In addition, cultural capital is understood as the local community knowledge to bouncing back crisis. This suggests that social-cultural capital developed during post-disaster reconstruction, should be reinforced in order to generate a sustainable urban development along the time.

The work proposes an empirical approach of the problem, identifying social-cultural indicators. Interviews and surveys have been carried out to the relevant local stakeholders during the emergency and reconstruction phases. The evolutionary resilience from Walker and Salt (2006) has been defined as conceptual framework. They propose that, as result of a destructive event, the urban structure can change into adaptive cycle related to the spatial conditions and temporal interactions. The model has been applied to the case study of Dichato, a coast Chilean locality prone to tsunami and earthquake. As a conclusion, this work presents a discussion about the necessity to improve and strength local social-cultural capital to achieve the sustainable urban development.
\end{abstract}

\section{Introduction}

During the last decades, international community increasing recognition on the importance of risk and vulnerability reduction as crucial elements in reducing negative impact of natural hazard as essential for achieving sustainable development(UNISDR, 2004). According to Sendai framework for Disaster Risk Reduction (2015-2030), the investment on risk reduction should generate more benefit to the community, through avoiding future losses by reinforcing the capacity to face and recovering from natural events. Disasters, which are expected will increased in intensity and frequency due to climate change, represent an obstacle for the sustainable development achievement, especially in developing countries where the mortality and economic loss are extremely higher than in the others (UNISDR, 2015).

Due to the global warming emergency, organizations and authorities have focused the attention on the adaptation to changes produced by disaster. It shows a change in

\footnotetext{
${ }^{1}$ Sustainable, Resilience and urban Regeneration Research Group, Department of Planning and Urban

Design, Universidad del Bío-Bío.

2Planning and Urban Design department of University of Bío-Bío (UBB), Chile.

${ }^{3}$ Associate professor of Project Appraisal at Department of Architecture and Urban Study (DAStU) -

Polytechnic of Milan (PoliMi) - Italy.

${ }^{4}$ Architect of the Pontifical Catholic University of Valparaiso, Doctor in urbanism of Karlsruhe Institute of

Technology in Germany.
} 
disaster approach where there are an understanding that the change is unavoidable, thus communities have to develop new capacities, reinforce them and improve they ability to recover after disaster (Carriquiriborde, 2012). In other word, communities have to be more resilient.

Several studies on resilience focus on the capacity of system, exposed to threat, to resist, absorb and maintain basic functionality. But, there is another aspect related with the resilience that concern the capacity of system to be flexible, adapting to change and reorganizing a new equilibrium state (Folke, 2006). In a social-ecological systems (SES), disaster could offer the opportunity for new development, reorganizing the system and promoting innovation grow-up (Folke, 2006; Holling, 2001).

Thanks to the SES approach, cities resilience could be understood as a multidimensional complex systems, where spatial mosaic sustains social and ecological functions(Pickett, Cadenasso, \& Grove, 2004). Therefore the main challenge is to understand the dynamic among different dimensions and develop governance systems able to drive the recovery toward improve resilience capacity of communities. Thus, post-disaster reconstruction could offer the opportunity for reorganizing urban community, in both spatially and socially, into a more resilient status.

The aim of this research is analyse the changes produced into urban community during post-disaster emergency and reconstruction in order to evaluate the capacity of systems to reorganize into a new state. The social and cultural capital have been investigated in order to assess the capacity of community to learn from the event and capitalize it, building more resilient society.

After the theoretical background on social-cultural capital, this paper presents the case of Dichato, a small city located in the middle-south of Chilean coast. Dichato was affected to earthquake and tsunami on $27^{\text {th }}$ February, 2010, which damages seriously the urban environment. The huge reconstruction processes were entailed with the aim to provide housing to people left homeless after tsunami and improve sustainability and quality of life as well. Citizen was involved into the emergency management and then into the reconstruction process, changing pre-existing social organization. Surveys and interviews to key actors were collected during emergency and reconstruction phase and the comparison between the two situations provide information about changes in social and cultural capital (Section 3 and 4). Finally, the discussion on the need to improve cultural capital and strength social cohesion as well as institutional commitment is presented in the conclusions (Section 5).

\section{Theoretical Framework of social-cultural capital}

The concept of resilience emerges from ecology to study the system response when exposes to external perturbation. Resilience can be defined as "the capacity of a system to absorb disturbance and reorganize while undergoing change so as to still retain essentially the same function, structure, identity, and feedbacks." (Walker, Holling, Carpenter, \& Kinzig, 2004, p. 5). Holling (2001) proposes the approach to complexity of human and natural systems as a "self-organized" system to explain the capability to develop complex adaptive systems, in which multiple configurations are possible depending on perturbation. Hence, resilience should analysed using the dynamic 
development of complex adaptive systems with interaction across spatial and temporal scale. Holling's view of resilience springs from his understanding of natural systems as dynamic and being away from an 'equilibrium' or stable state at any point, instead being organised in a domain of attraction in which different elements of a system are organised around different, individual equilibriums (Bahadur, Ibrahim \& Tanner, 2010).

The "adaptive cycle" is an heuristic model developed from the observation of ecosystem dynamics exposed to perturbation (Folke, 2006; Holling, 2001; Walker et al., 2004). The adaptive cycle recognize four phases of development connected among them (figure 1). The cycle shows the progression from the conservation ( $\mathrm{r}$ ), which represents the stability situation before the perturbation, to exploitation $(\mathrm{K})$, which is the phase after the reorganization when a system accumulates resources and increases the control over them. The phases of release $(\Omega)$ represents the crisis of system after the perturbation, when, the system quickly re-organize itself $(\alpha)$. The cycle from $\Omega$ to $\alpha$, named "back loop", is inherently unpredictable and highly uncertain, the previous system capitals strengthen themselves in a novel combination and resilience is high. The stage $\alpha$ is crucial for the system reorganization, because allow unexpected combination and innovation can arise. The innovation are tested, some fail, but other survive and adapt to succeeding stage from $\mathrm{K}$ to $\mathrm{r}$ (Holling, 2001).

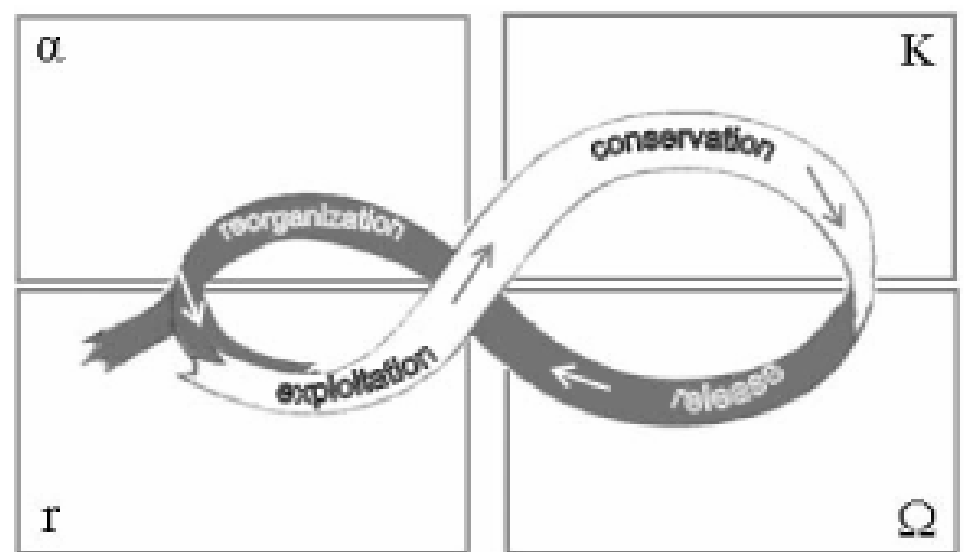

Figure 1. Adaptive Cycle of SES resilience. Source: Holling 2001

Hence, resilience is the ability of system to use the crisis as opportunity to change and adapt into a novel combination. In relation with human system, resilience can be understood as the capacity to learn from the event, developing innovative solution and improving social and cultural capital.

Relating the concept of social capital, Norris (2008) propose the definition as the "individual invest, access, and use resources embedded in social networks to gain returns" (Norris, Stevens, Pfefferbaum, Wyche, \& Pfefferbaum, 2008, p. 137). For communities affected by risk, the social capital is positive for the resilience because it provides group networks, with reciprocal links, which are able to establish supportive interactions and cooperative decision making processes. Local organizations (to better respond to local needs) that are able to coordinate and collaborate, promote adaptation 
and timely recovery of community. Then, social capital provides "social support" that is a resource useful for the resilience. Social support could be offered by family, friendship networks, but social capital encompasses relationship between individuals and neighbourhood or community. Thus, aspects as the "sense of community", the "place attachment" and the "citizen participation" are relevant for the construction of social capital (Norris et al., 2008). About citizen participation, several authors believed that is fundamental element for community resilience. Reconstruction after disaster should involve affected person into decision making process about the place where they will live (Bryant \& Allan, 2013; GFDRR, 2015; Norris et al., 2008).

The Cultura Capital, can be defined as widely shared legitimate culture made-up of high status cultural signals (attitude, preferences behaviours and goods) used in the direct or indirect social and cultural exclusion (Lamont and Lareau, 2007). In the case of risk exposition, the information seems to be the cultural signal. The appropriate information to prevent and proceed in case of emergency, generates a strong sense of recovery and control of the situation, which has been called Cultural Capital, and that knowledge that has been passed on from generation to generation. Moser (1998) indicates that: "if the community has more cultural capital less vulnerable it is and the greater is its erosion the larger is its insecurity".

\section{The Case Study}

The essay presents the case of Dichato, small city located in the middle-south coast of Chile, which the 8.8 MW earthquakes and the consequent tsunami hit on February 27 of 2010.

Dichato is located between the coordinates $36^{\circ} 33^{\prime}$ South latitude and $72^{\circ} 55$ "longitude West, in the Bay of Coliumo, 38,9km from the regional capital: Concepción, and $11 \mathrm{~km}$ from the communal capital: Tomé. The main access from the South is the route 150 from Concepción and the O-14 route from Tomé. In turn from North, the main route is O-14 that joins the locality with Puda and O-250 route that links it whith Menque.

The pre-event urban system shows high vulnerability to tsunami (Cartes Siade, 2013) due to buildings with low height (mainly one floor house) and poor resistance to wave impact (wood frame). In addition, the location of Coliumo Bay is prone to tsunamis, as demonstrated by repetitive events that have affected Dichato throughout history.

The 2010 earthquake and tsunami produced enormous damages to residential and commercial areas (Cartes Siade, 2013). The tsunami inundation height was between 8 to $10 \mathrm{mt}$, which destroyed the seafront and the downtown (figure 2). It affected more than 450 families and the economic structure, mainly based on fishing industry and tourism. After the earthquake, the lack of information, the difficulty in communication systems, the failure of early-warning-system and the contradiction in the instructions given by the authorities, it caused many people returned to their homes in a dangerous set-up because of the tsunami.

In Dichato, the reconstruction activities begun one year after the disaster, and many of them are still in progress. A comprehensive master plan has been implemented, based on cross-sector integration and a betterment approach. Emphasis on mitigation has been 
promoted by building anti-tsunami barriers, a mitigation park on the seafront, and embankment to reduce flooding level. Additionally, new residential areas were located in safety zones, though they built houses were built in the flood zone (Bio-Bio Regional Government, 2010).

To define survey sample, citizen that lived into inundation area before the tsunami, was selected because they were the most damaged and reallocated in the reconstruction. The inundation zone was defined according to the study "Definition of differentiated Areas of danger of Tsunami" developed by the Catholic University (PUC, 2010).

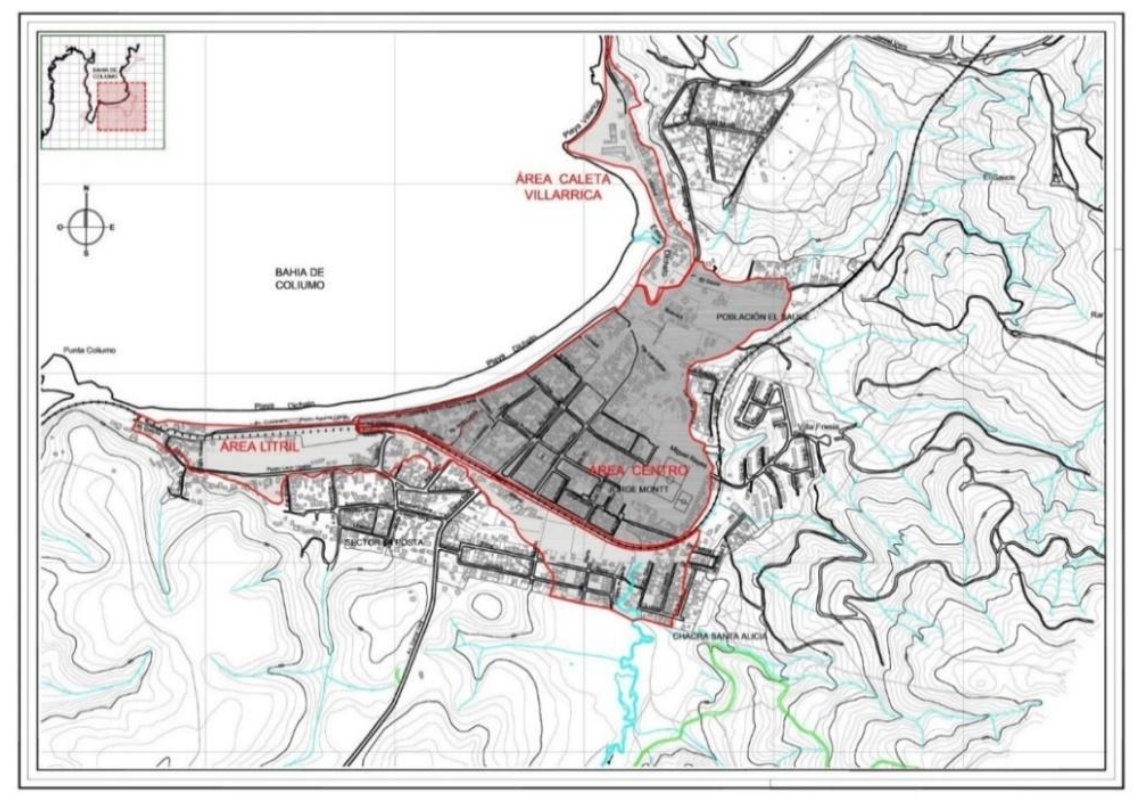

Figure 2. Map of Dichato with inundation zone (grey area) Source: Own Preparation

\section{Research Methodology}

According to the SES approach, the social and cultural capital has been analyzed during the release and reorganization, which can be allocated with post-disaster emergency and reconstruction phases respectively. In these phases it is possible assess the capacity of community to manage the pre-existent vulnerabilities for the reorganization and recovery of basic functions. In other words, community resilience is assessed as ability to adapt to new conditions.

The analysis has been focused in the selection of variables, whose evaluation will be able to generate resilientes conditions. Baker (2009) points out that the vulnerability in disasters situation is defined as contextual and proactive, in other words, here the members of a community define its perception of strength and weakness, as also the grade of risk accepted, without taking in consideration the perception of the specialists or external agents. Reason why each of the social variables is analyzed by means of interviews and/or surveys realized to the community and to agents' keys of the 
reconstruction process. The survey campaign was conducted during the emergency and reconstruction phase, with the aim to assess cultural and social capital in both conditions. The comparison between the two phases lets to understand after the disaster changes and if these modifications tend to resilience.

\section{Survey}

The citizens selected for the survey was composed by 45 people organized into three different age groups: $12-15,25-45$ and more than 45 years old, $50 \%$ women and $50 \%$ men. Five questions form the survey, two for evaluating cultural capital and three to assess the social capital.

The cultural capital has been assessed as the knowledge of people about risk and what they should do after the disaster. For Dichato, it means if people had information that the earthquake could generate tsunami, the foreseen extension of inundation zone, where secure areas and evacuation routes are placed. The information provided by authorities, like as warning messages, is key to save human lives. Although, during unpredictable events as earthquakes, early-warning-systems could fail, therefore pre-existent knowledge about evacuation behavior and evacuation route is crucial to mobilize people timely. In this work, cultural capital means preparedness and awareness to face tsunami risk (Murakami, Takimoto, \& Pomonis, 2012).

To assess the social capital, the capacity of community to organize into groups and provide "social support" for the recovery, is evaluated. The questions during the emergency focuses on collect information about the capacity of local organization to help in the emergency management. After disaster, due to "state of necessity", social capital arises supported by institutions, voluntaries and ONGs.

During post-emergency phase, when external institutions stopped to operate, new organizations should maintain functioning and support the reconstruction as well. Resilient communities are able to capitalize local groups and networks to support recovery, to collaborate each other, reaching agreements and organizing demands to local authorities. Thus, survey questions and interviews focused on determining the individual commitment on collaborate with local organizations and if local organization really worked for community benefit and equal distribution of outcomes.

Table 1. Survey questions and interpretation

\begin{tabular}{|l|l|l|l|}
\hline CONCEPT & INDICATORS & INTERPRETATION & QUESTION \\
\hline \multirow{4}{*}{$\begin{array}{l}\text { Cultural } \\
\text { Capital }\end{array}$} & $\begin{array}{l}\text { Information } \\
\text { Level }\end{array}$ & $\begin{array}{l}\text { Information and communication } \\
\text { are vital in emergency period. The } \\
\text { inhabitants need adequate } \\
\text { information about the catastrophe } \\
\text { and procedures options and they } \\
\text { need it quickly. Norris(2008) }\end{array}$ & $\begin{array}{l}\text { Question } \mathbf{N}^{\circ} \text { 1: Did } \\
\text { you receive } \\
\text { appropriate } \\
\text { information after } \\
\text { disaster regarding what } \\
\text { you had to do and the } \\
\text { where are location of } \\
\text { safety areas? }\end{array}$ \\
\cline { 2 - 5 } & $\begin{array}{l}\text { Information } \\
\text { Source }\end{array}$ & $\begin{array}{l}\text { The individuals and the } \\
\text { communities will take adaptive }\end{array}$ & $\begin{array}{l}\text { Question } \mathbf{N}^{\circ} \text { 2: How } \\
\text { did you obtain the }\end{array}$ \\
\hline
\end{tabular}




\begin{tabular}{|c|c|c|c|}
\hline & & $\begin{array}{l}\text { strategies, which will mobilize the } \\
\text { values, networks and share capital } \\
\text { to anticipate and to react to } \\
\text { potential disasters. Adger }(2005)\end{array}$ & information? \\
\hline \multirow{3}{*}{$\begin{array}{l}\text { Social } \\
\text { Capital }\end{array}$} & $\begin{array}{l}\text { Community } \\
\text { Organization }\end{array}$ & $\begin{array}{l}\text { The inability, dependence and the } \\
\text { reduced capacity of individuals } \\
\text { and communities to organize limit } \\
\text { it's their organization capacity in } \\
\text { pursuit of its own interests. Baker } \\
(2009)\end{array}$ & $\begin{array}{l}\text { Question } \mathbf{N}^{\circ} \text { 3: How } \\
\text { did you obtain the } \\
\text { information? }\end{array}$ \\
\hline & $\begin{array}{l}\text { Coordination } \\
\text { with authorities }\end{array}$ & $\begin{array}{l}\text { There cannot be effective } \\
\text { management of the risk if there is } \\
\text { not also community management. } \\
\text { Cilento (2005) }\end{array}$ & $\begin{array}{l}\text { Question } \mathbf{N}^{\circ} 4 \text { : } \text { How } \\
\text { do you assess the } \\
\text { organization } \\
\text { coordination and } \\
\text { neighbourhood group } \\
\text { with authorities? }\end{array}$ \\
\hline & $\begin{array}{l}\text { Pre-event } \\
\text { Organization } \\
\text { Assessment }\end{array}$ & $\begin{array}{l}\text { The weakness of the State } \\
\text { structure is due to the lack of } \\
\text { political decision; focus only on } \\
\text { emergency and excessive } \\
\text { institutionalization that does not } \\
\text { incorporate local governments. } \\
\text { Cardona (2005) }\end{array}$ & $\begin{array}{l}\text { Question } \mathbf{N}^{\circ} \text { 5: How } \\
\text { do you assess the } \\
\text { answer } \\
\text { neighbourhood groups } \\
\text { after the event? }\end{array}$ \\
\hline
\end{tabular}

Source: Own Preparation

\section{Interviews}

Table 2. Interviewed list

\begin{tabular}{|l|l|}
\hline NAME & ORGANIZATION / JOB \\
\hline L.A & Dichato's citizen movement assembly \\
\hline J.C & Bahía Azul Committee \\
\hline M.P & Housewife Condominio Azul \\
\hline N.A & Huallafe Lefuen Association \\
\hline M.V & Housewife Committe \\
\hline G.S & Don Mino Restaurant \\
\hline A.R & Restaurants Association \\
\hline
\end{tabular}

Source: Own Preparation

interviewed is described in the Table 2.
Seven interviews were done to key stakeholders such us traders, new leaders, and social leaders, which faced the emergency and reconstruction processes in Dichato. The key stakeholders' interviews had the objective to identify affected subjects in different ways in the emergency phase and also to identify the commitment in the process of reconstruction post disaster. Finally the list of persons

\section{Results and Discussions}

In this section, the results of surveys and interviews are presented and discussed. In order to normalize survey results, answers are organized into the follows levels: Good (G), Middle Good (MG), Middle Bad (MB) and Bad (B). "Good" means high level of social/cultural capital, while "Bad" means low social/cultural capital. Thus, the evaluation of resiliency as capacity to learn from the event and improving social and cultural capital is obtained by comparing conditions during emergency and 
reconstruction.

\section{Cultural Capital}

The cultural capital is evaluated according the information level and the ability of citizens to improve their preparedness to face future events. Regarding the information level, the survey shows that few citizens has previous information about what they needs doing during emergency (Figure 3a) and institutional communication was poor and confused (Figure $3 \mathrm{~b}$ ). In fact, only the $20 \%$ of respondents received information during the evacuation from local authorities. A.R. said that, after the earthquake the police and fire station were completed destroyed, although until the threat of tsunami, the policemen and firemen were warning the community to evacuate.

During the reconstruction, people recognized that they received more information about evacuation process, escape route and secure areas. According to results, everybody gain knowledge needed during the emergency. Media and local authorities provided more information and organizing courses and evacuation drills to test response in the event of emergency. In the interview done to G.S., she explained: "During an earthquake you have to run, there is no other choice. If the magnitude is over eight, you have to run immediately." Thus, citizen said that they improve their knowledge and preparedness to manage future emergency thanks to personal experience.
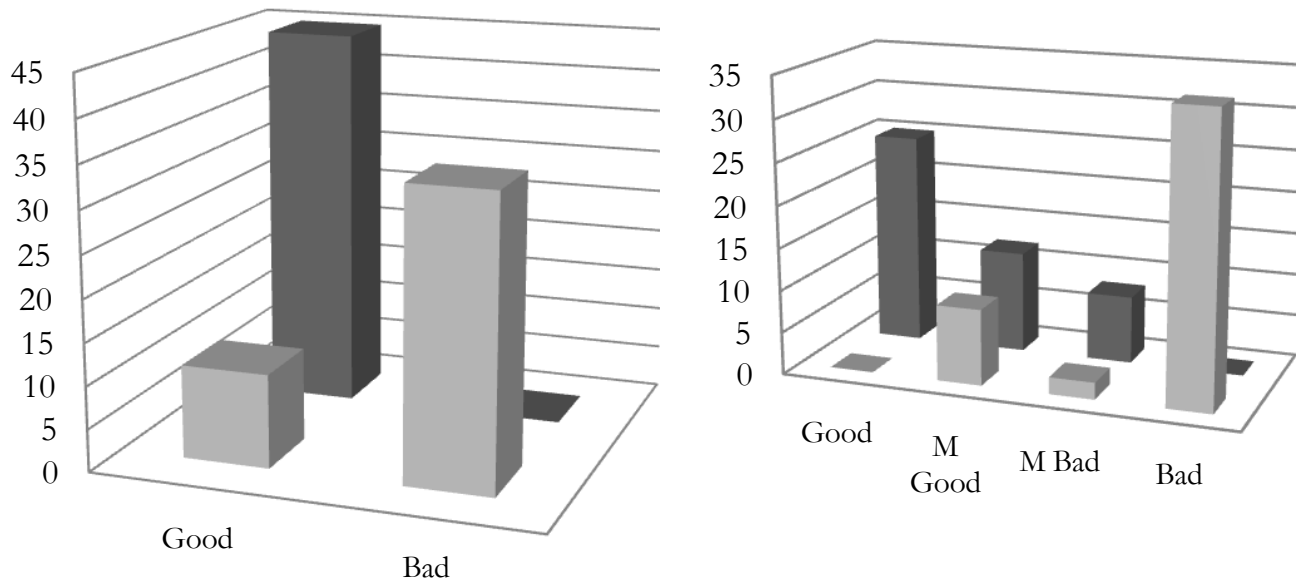

\begin{tabular}{|l|c|c}
\cline { 2 - 3 } \multicolumn{1}{c|}{} & Good & Bad \\
\hline$\square$ Emergency & 11 & 34 \\
\hline$\square$ Reconstruction & 45 & 0 \\
\hline
\end{tabular}

\begin{tabular}{|l|c|c|c|c}
\cline { 2 - 5 } \multicolumn{1}{c|}{} & Good & $\begin{array}{c}\text { M } \\
\text { Good }\end{array}$ & M Bad & Bad \\
\hline Emergency & 0 & 9 & 2 & 34 \\
\hline$\square$ Reconstruction & 25 & 12 & 8 & 0 \\
\hline
\end{tabular}

a)

b)

Figure 3a-3b. Survey results a) Information level and b) Information Sources. Source: Authors elaborated. 


\section{Social Capital}

After the disaster, social capital arises spontaneously drove by the need to reorganize the system and recover functionality. The community re-organizes itself around new leaders, with the aim to manage emergency and ordering requests for the reconstruction. People, especially community leaders, improve their social commitment by collaborating, being involved in reconstruction activities, helping people each other and reaching agreements regarding community issues.

According to the $80 \%$ of respondents in Dichato, during the emergency communities organize itself around new leaders, which emerged and took the role of main responsible of group or community. The remaining $20 \%$ of respondents was organized around the family as main resources for the emergency management and recovery activities (Figure 4. a). During the reconstruction, the social capital is improved thanks to the new leaders and the citizen participation into networks, formal or informal groups, as well as due to the establishment relationship. However, in Dichato only the $13 \%$ of respondents collaborated with new organizations grew-up to manage reconstruction and economic recovery. Several interviewers said that the opinion of the new leaders close to Government party was the most important in the reconstruction processes. "The Government made the reconstruction without citizens" according to L.A. interview.

Regarding the coordination between neighbourhood groups (NG) and local authorities, during the emergency citizen did not be taken into account on the decision making processes, according to the $66 \%$ of responding (Figure 4.b). The involvement of NG improved during the reconstruction. The $48 \%$ of respondent recognized the NG role during negotiations with government. Citizens organized themselves according the allocation of new neighbourhoods, each one whit a leader and a committee, as described in the interviews.

Concerning the organization assessment, results is pretty similar to the community organization and coordination with the authorities. During the emergency, the response of neighbourhood organizations was bad (55\%), but it improve during reconstruction $(28 \%)$ (Figure 4.c). Citizens organized themselves around the NG with the aim of facilitating the reconstruction process and timely recover functionality. Even so, the emergence of new leaders was dictated by individual convenience more than the benefit of the whole community. In fact, surveys show a low level of satisfaction with the role played by NG (35\% is bad and middle bad). This perception also appears in the J.C. interview, which said: "The only relevant opinion was the view of allied leaders. They organized participatory event, but I did not participate". 


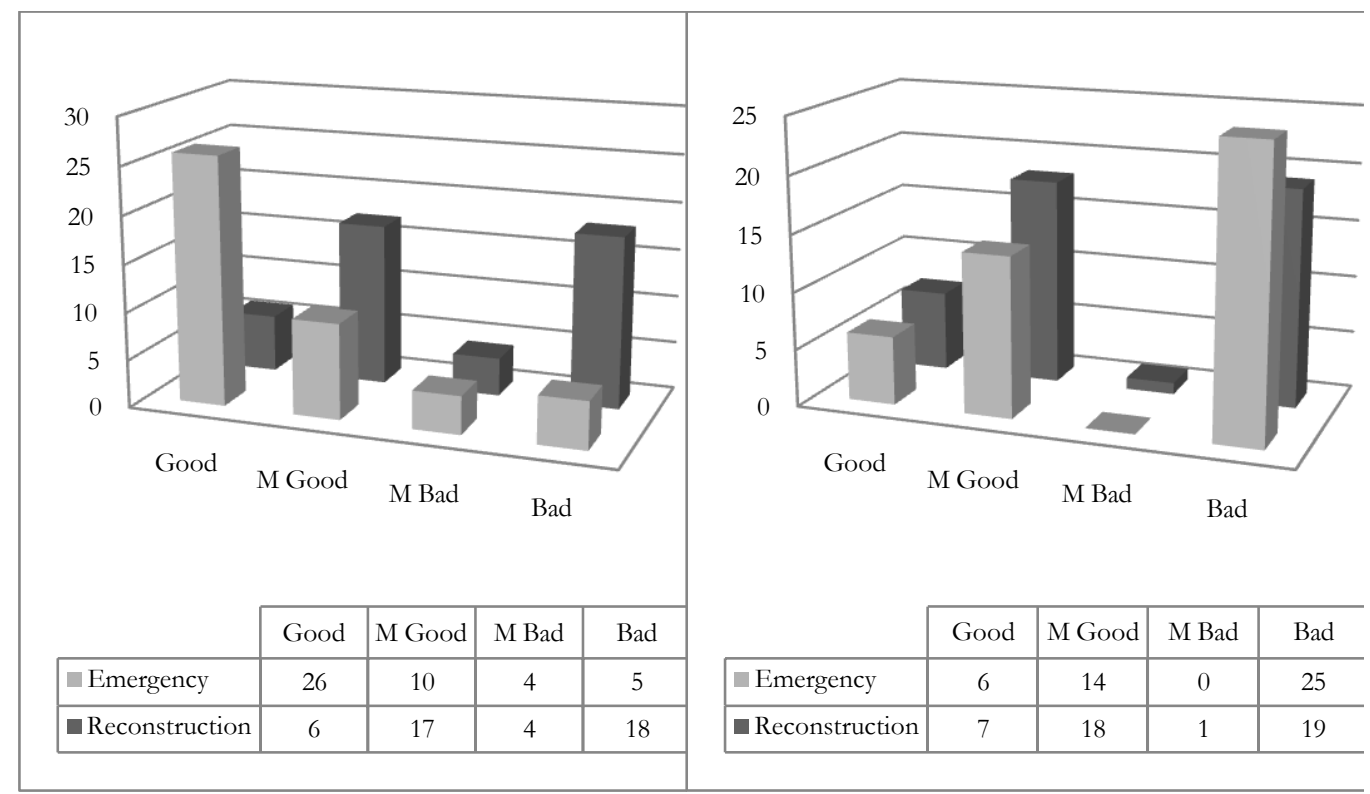

a)

b)

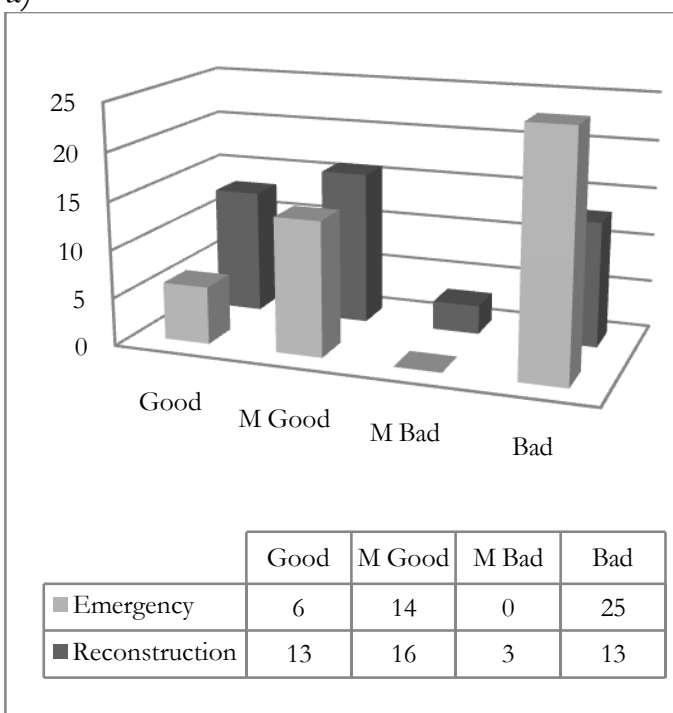

c)

Figure 4 Results of survey a) Community Organization, b) Coordination with authorities and c) Pre-event Organization Assessment.

\section{Conclusions}

\section{Cultural Capital}

Norris (2008) points out that "The information and communication are vital in 
emergency period. The inhabitants need information about the catastrophe and the options of procedures and they need them quickly" (Norris et al., 2008, p. 140). Therefore, the misinformation increases the vulnerability, generating a rigid system and hampering the quickly recovery. On the other side, the knowledge can increase the resilience capacity, preparing the community to the change and forging its recovery.

The study conducted in Dichato shows interesting result. People, before disaster did not receive knowledge about tsunami and information about evacuation and safety areas. After earthquake, early-warning-systems failed, media and authorities provided confused instruction that causes several human lost. Despite that, citizens, after earthquake instinctively they seek refuges on the hills. It shows that people has cultural knowledge about the local manage of threats, which was handed down over time from father to son. During the reconstruction, citizen received more information about security measures and evacuation procedure. Authorities organized educational activities, but according surveys and interviews, people learning derived from the lived experience. This suggests that Chilean people are culturally more prepared to face natural disaster due to exposition to multiples threats.

\section{Social Capital}

Here it appears like decider the absence of coordination of the community with the local authorities "A greater diversity in the organization of services, a greater flexibility, a variety of actors, even a transformation of the forms that local democracy might assume, can reinforce the sense of resilience in a community effected by a natural disaster" (Le Galls, Stren, 2000, p.3).

Many people did not collaborate in any pre- event organization, broking the local links with their NG, due to the citizen relocation into emergency shelters. Thus, social cohesion arises during the emergency, promote by the new leaders, broking down the pre-event local organizations.

This is reflected in the low evaluation of municipality, central government as well as the coordination between these institutions. The community perceives that its demands are not taken into account and their problems are not resolved. It appears like decider the low incidence of the Neighbors' opinions in the decision making, what is perceived negatively by the community.

The Social Capital is understood as the new leaders that appear in the social structure, which support the post emergency and reconstruction process. This social capital supports community recovery in emergency situation (Dynes, 2012), but during the reconstruction process this support disappears, because personal interests put above the common benefit of the community.

Therefore, it is important not only to the emergence of Social Capital, but also the importance of linking it to the local authorities. In the case study the new leaders assume a political role instead of a social one, which is viewed in a negative way by the citizen and discouraged the individual commitment in the reconstruction process.

In addition, a subsidiary culture has been revealed. The community depend on the institutional support, which does not allow the generations of the networks and participation with the local authorities. 


\section{References}

Aditya V, Maggie I. and Thomas T., (2010) "The resilience renaissance? Unpacking of resilience for tackling climate change and disasters - Strengthening Climate Resilience" Discussion Paper 1, Institute of Development Studies at the University of Sussex, Brighton (UK) cited in page 2

Bryant, M., \& Allan, P. (2013). Open Space Innovation in Earthquake Affected Cities. Retrieved from http://www.intechopen.com/books/approaches-to-disaster-management-examining-the-

implications-of-hazards-emergencies-and-disasters/open-space-innovation-in-earthquake-affectedcities

Carriquiriborde, I. R. (2012). Th e structure of vulnerability within a large disaster risk scenario, 77(2000), $75-88$.

Cartes Siade, I. (2013). Dichato desde la crisis a la reconstrucción. Un modelo de gestión de riego y resiliencia. Urbano, 33-40.

Dynes, R. (2012) "The importance of Social Capital in Disaster Response" Preliminary Paper $\mathrm{N}^{\circ} 327$. University of Delaware. Published by Disaster Research Center.

Folke, C. (2006). Resilience: The emergence of a perspective for social-ecological systems analyses. Global Environmental Change, 16(3), 253-267. doi:10.1016/j.gloenvcha.2006.04.002

GFDRR. (2015). Resilient Recovery: An Imperative for Sustainable Development. Washington.

Holling, C. S. (2001). Understanding the complexity of economic, ecological, and social systems. Ecosystems, 4(5), 390-405. doi:10.1007/s10021-001-0101-5

Lamont M., Lareau A. (1998). Cultural capital: Allusions, Gaps and Glissandos in Recent Theoretical Developments, Sociological Theory, 6(2): 153-168.

Moser, C., "The assets vulnerability Framework: Reassessing Urban Poverty Reduction Strategies" World Development. Vol 26, N¹, p1-19 1998. Washington DC.

Murakami, H., Takimoto, K., \& Pomonis, A. (2012). Tsunami Evacuation Process and Human Loss Distribution in the 2011 Great East Japan Earthquake - A Case Study of Natori City , Miyagi Prefecture -. 15th World Conference on Earthquake Engineering, (2011), 1-10. Retrieved from http://www.iitk.ac.in/nicee/wcee/article/WCEE2012_1587.pdf

Norris, F. H., Stevens, S. P., Pfefferbaum, B., Wyche, K. F., \& Pfefferbaum, R. L. (2008). Community resilience as a metaphor, theory, set of capacities, and strategy for disaster readiness. American Journal of Community Psychology, 41(1-2), 127-150. doi:10.1007/s10464-007-9156-6

Pickett, S. T. A., Cadenasso, M. L., \& Grove, J. M. (2004). Resilient cities: meaning, models, and metaphor for integrating the ecological, socio-economic, and planning realms. Landscape and Urban Planning, 69(4), 369-384. doi:http://dx.doi.org/10.1016/j.landurbplan.2003.10.035

Putman, R. (1993) "The prosperous Community. Social Capital and Public Life". The American Prospect. 1993. USA

Stren, R. (2000) "Nuevos enfoques para la gobernancia urbana en América Latina". Internet: www.idrc.ca/es/ev-22827-201-1-DO_TOPIC.html.

UNISDR. (2004). Living with risk: a global review of disaster reduction initiatives. Strategy (Vol. 1). doi:9211010640

UNISDR. (2015). Marco de Sendai para la Reducción del Riesgo de Desastres 2015-2030 (Vol. 69/283). Retrieved from http://www2.ohchr.org/spanish/bodies/hrcouncil/docs/gaA.RES.60.1_Sp.pdf

Walker, B., Holling, C. S., Carpenter, S. R., \& Kinzig, A. (2004). Resilience, adaptability and transformability in social--ecological systems. Ecology and Society, 9(2), 5. 